\title{
Effect of gallic acid on the larvae of Spodoptera litura and its parasitoid Bracon hebetor
}

\author{
Abhay Punia, Nalini Singh Chauhan, Drishtant Singh, Anup Kumar Kesavan, \\ Sanehdeep Kaur \& Satwinder Kaur Sohal ${ }^{\bowtie}$
}

The antibiosis effect of gallic acid on Spodoptera litura F. (Lepidoptera: Noctuidae) and its parasitoid evaluated by feeding six days old larvae on artificial diet incorporated with different concentrations (5 ppm, 25 ppm, 125 ppm, 625 ppm, 3125 ppm) of the phenolic compound revealed higher concentration ( $\mathrm{LC}_{50}$ ) of gallic acid had a negative impact on the survival and physiology of $S$. litura and its parasitoid Bracon hebetor (Say) (Hymenoptera:Braconidae). The mortality of S. litura larvae was increased whereas adult emergence declined with increasing concentration of gallic acid. The developmental period was delayed significantly and all the nutritional indices were reduced significantly with increase in concentration. Higher concentration ( $\mathrm{LC}_{50}$ ) of gallic acid adversely affected egg hatching, larval mortality, adult emergence and total development period of $B$. hebetor. At lower concentration ( $\mathrm{LC}_{30}$ ) the effect on $B$. hebetor adults and larvae was non-significant with respect to control. Gene expression for the enzymes viz., Superoxide dismutase, Glutathione peroxidase, Peroxidase, Esterases and Glutathione $S$ transferases increased while the total hemocyte count of $S$. litura larvae decreased with treatment. Our findings suggest that gallic acid even at lower concentration $\left(\mathrm{LC}_{30}\right)$ can impair the growth of $S$. litura larvae without causing any significant harm to its parasitoid $B$. hebetor and has immense potential to be used as biopesticides.

Parasitoids have a very close association with the insect pests and their host plants. They are natural biological control agents which can regulate the pest population. The pest populations are also kept in check by plant phytochemicals, a majority of which evolved as defensive compounds which deter herbivory. These chemicals commonly known as secondary metabolites or allelochemicals regulate pest population by imparting toxic or feeding deterrent activity in insect pests ${ }^{1}$. Variations in these compounds can also affect the fitness of natural enemies of insect pests.

Phenolics are plant secondary metabolites widely distributed in plants, and are helpful to them in a number of ways such as by providing physical barriers as cell wall bound phenolics, lignin suberin, and cuticle associated phenolics as well as stored compounds that have deterring and insecticidal effect on herbivores ${ }^{2}$. These are reported to be potential sources of new natural drugs, antibiotics, insecticides and herbicides ${ }^{3,4}$. Induced defense response in plants against herbivore attacks lead to an increase in the production of foliage phenolic content ${ }^{5}$. Phenolic acids are a diverse class of phenols in plants and are also known as hydrobenzoates, principle component of which is gallic acid. The formation of gallic acid, a base unit of gallotanins, occurs mainly via the shikimic acid pathway from 3-dehydroxyshikimic acid. However, it can also be formed through alternative routes from hydroxybenzoic acids. Galloylation of gallic acid also results in the synthesis of the hydrolysable tannins viz., gallotannins and ellagitannins ${ }^{6}$. Plant allelochemicals play a key role in the survival of herbivore and are lately being extensively explored as potential alternative to synthetic pesticides. However, plant alleleochemicals in the host diet can not only affect the fitness and survival of the phytophagous insect but can also impact the growth, development and survival of parasitoid because the quality of the host for its parasitoid ${ }^{7,8}$ is determined by the quality of the host's nutrient intake ${ }^{9}$. Several studies have also reported that secondary compounds ingested by the host can negatively affect parasitoids $\mathrm{s}^{10-13}$. Therefore before incorporating these compounds in pest management programmes, it is essential to study their effect not only on the insect pest but also on its parasitoids as the latter play a key role in limiting insect pest population.

$S$. litura is an indigenous pest of a variety of crops in South Asia and was found to cause $26-100 \%$ yield loss in groundnut ${ }^{14}$. Mainly due to development of insecticide resistance, its frequent outbreaks have become more common ${ }^{15,16}$. B. hebetor, a gregarious ectoparasitoid attacking some storage moths ${ }^{17}$, has been intensively studied because of its importance as a biological control agent of the moths ${ }^{18,19}$. Biology of $B$. hebetor varies with the host 


\begin{tabular}{|l|l|l|l|l|l|l|}
\hline Concentrations (ppm) & Larval mortality (\%) & Adult emergence (\%) & Larval period (days) & Pupal period (days) & $\begin{array}{l}\text { Total development period } \\
\text { (days) }\end{array}$ & Pupal weight (mg) \\
\hline Control & $3.33 \pm 3.33^{\mathrm{a}}$ & $90.00 \pm 4.47^{\mathrm{a}}$ & $19.39 \pm 0.47^{\mathrm{a}}$ & $13.56 \pm 0.59$ & $33.38 \pm 0.88^{\mathrm{a}}$ & $254.16 \pm 6.84^{\mathrm{a}}$ \\
\hline 5 & $6.67 \pm 4.22^{\mathrm{a}}$ & $80.00 \pm 5.16^{\mathrm{a}}$ & $20.96 \pm 0.49^{\mathrm{ad}}$ & $14.46 \pm 0.58$ & $35.30 \pm 0.40^{\mathrm{ab}}$ & $253.78 \pm 7.01^{\mathrm{a}}$ \\
\hline 25 & $30.00 \pm 8.56^{\mathrm{ab}}$ & $50.00 \pm 6.83^{\mathrm{b}}$ & $22.58 \pm 0.53^{\mathrm{d}}$ & $14.39 \pm 0.57$ & $37.45 \pm 1.09^{\mathrm{b}}$ & $231.37 \pm 9.51^{\mathrm{a}}$ \\
\hline 125 & $46.67 \pm 4.22^{\mathrm{bc}}$ & $26.67 \pm 6.67^{\mathrm{c}}$ & $30.92 \pm 0.32^{\mathrm{b}}$ & $14.79 \pm 0.72$ & $43.74 \pm 0.73^{\mathrm{c}}$ & $155.87 \pm 7.08^{\mathrm{b}}$ \\
\hline 625 & $46.70 \pm 11.20^{\mathrm{bc}}$ & $16.67 \pm 6.15^{\mathrm{cd}}$ & $29.00 \pm 0.30^{\mathrm{c}}$ & $16.00 \pm 0.57$ & $43.75 \pm 0.83^{\mathrm{c}}$ & $174.43 \pm 9.70^{\mathrm{b}}$ \\
\hline 3125 & $70.00 \pm 13.40^{\mathrm{c}}$ & $0.00 \pm 0.00^{\mathrm{d}}$ & $32.91 \pm 0.22^{\mathrm{e}}$ & - & - & $156.22 \pm 4.34^{\mathrm{b}}$ \\
\hline F-value & $9.39^{* *}$ & $43.96^{* *}$ & $193.54^{* *}$ & ns & $42.82^{* *}$ & $38.53^{* *}$ \\
\hline
\end{tabular}

Table 1. Larval mortality, adult emergence, larval period, pupal period, total developmental period, pupal weight of $S$. litura when 6 days old instar larvae were fed on different concentrations of gallic acid. ${ }^{*}$ Significant at $1 \%$, ns Non-Significant. Values are Mean \pm SE. Means followed by the same letter within the columns are not significantly different according to Tukey's test at $p \leq 0.05$.

\begin{tabular}{|l|l|l|l|l|l|l|}
\hline Concentrations (ppm) & Larval mortality (\%) & Adult emergence (\%) & Larval period (days) & Pupal period (days) & $\begin{array}{l}\text { Total development period } \\
\text { (days) }\end{array}$ & Pupal weight (mg) \\
\hline Control & $3.33 \pm 3.33^{\mathrm{a}}$ & $90.00 \pm 4.47^{\mathrm{a}}$ & $96.68 \pm 0.27^{\mathrm{a}}$ & $13.62 \pm 0.58^{\mathrm{a}}$ & $33.17 \pm 0.74^{\mathrm{a}}$ & $254.16 \pm 6.84^{\mathrm{a}}$ \\
\hline 5 & $26.67 \pm 4.21^{\mathrm{b}}$ & $46.67 \pm 4.21^{\mathrm{b}}$ & $22.39 \pm 0.60^{\mathrm{b}}$ & $15.33 \pm 0.21^{\mathrm{ab}}$ & $37.72 \pm 0.71^{\mathrm{b}}$ & $231.12 \pm 2.97^{\mathrm{ab}}$ \\
\hline 25 & $50.00 \pm 4.40^{\mathrm{c}}$ & $30.00 \pm 4.47^{\mathrm{c}}$ & $27.92 \pm 0.32^{\mathrm{c}}$ & $15.94 \pm 0.34^{\mathrm{bc}}$ & $43.78 \pm 0.54^{\mathrm{c}}$ & $214.80 \pm 5.33^{\mathrm{b}}$ \\
\hline 125 & $70.00 \pm 4.47^{\mathrm{d}}$ & $10.00 \pm 4.47^{\mathrm{d}}$ & $29.00 \pm 0.50^{\mathrm{c}}$ & $16.67 \pm 0.21^{\mathrm{bcd}}$ & $45.67 \pm 0.57^{\mathrm{c}}$ & $155.76 \pm 7.04^{\mathrm{c}}$ \\
\hline 625 & $90.00 \pm 4.47 \mathrm{e}$ & $3.33 \pm 3.33^{\mathrm{d}}$ & $35.33 \pm 0.33^{\mathrm{d}}$ & $17.67 \pm 0.33^{\text {cd }}$ & $52.67 \pm 0.33^{\mathrm{d}}$ & $135.17 \pm 2.89^{\mathrm{c}}$ \\
\hline 3125 & $93.33 \pm 4.21^{\mathrm{e}}$ & $0.00 \pm 0.00^{\mathrm{d}}$ & $36.00 \pm 0.00^{\mathrm{d}}$ & - & - & $110 \pm 0.00^{\mathrm{d}}$ \\
\hline F-value & $119.00^{* *}$ & $79.50^{* *}$ & $160.11^{* *}$ & $14.86^{* *}$ & $108.41^{* *}$ & $62.59^{* *}$ \\
\hline
\end{tabular}

Table 2. Larval mortality, adult emergence, larval period, pupal period, total developmental period, pupal weight of $S$. litura when 6 days old instar larvae were fed on different concentrations of azadirachtin. ${ }_{*}$ Significant at $1 \%$. Values are Mean \pm SE. Means followed by the same letter within the columns are not significantly different according to Tukey's test at $p \leq 0.05$.

age, nutritional status and freshness of the host ${ }^{20}$. The present study was therefore aimed at investigating the influence of gallic acid on the common cutworm, Spodoptera litura (F.) and its parasitoid, Bracon hebetor (Say).

\section{Results}

Effect on growth and development of S. litura larvae. Gallic acid incorporated diet when fed to the six days old larvae of $S$. litura significantly affected the growth, development and survival of S. litura larvae (Table 1). In gallic acid treated S. litura larvae, the larval mortality significantly increased in a dose dependent manner from $3.33 \%$ in control to $70 \%$ at $3125 \mathrm{ppm}$. The percentage adult emergence decreased with increase in concentration. No adult emerged at the highest concentration of $3125 \mathrm{ppm}$. At $625 \mathrm{ppm}$ the adult emergence was inhibited by $73.33 \%$ when compared with control. The larval period and total developmental period were delayed significantly after feeding larvae with diet having gallic acid when compared with control. The larval period was delayed by 13.52 days at 3125 ppm concentration while delay of 10.37 days in total developmental period was observed at $625 \mathrm{ppm}$ as compared to control. The pupal weight was also significantly lower at all the concentrations when compared with control. The $\mathrm{LC}_{30}$ and $\mathrm{LC}_{50}$ calculated on the basis of larval mortality were $52.44 \mathrm{ppm}$ and $402.80 \mathrm{ppm}$ concentrations, respectively. Growth and survival of azadirachtin treated positive control S. litura larvae was more adversely affected when compared to gallic acid fed larvae. At higher concentration of 3125 ppm, 93.33\% larval mortality was observed in azadirachtin fed larvae (Table 2). The larval period and total developmental period were also more prolonged in azadirachtin treated larvae. The $\mathrm{LC}_{30}$ and $\mathrm{LC}_{50}$ of azadirachtin fed larvae was $5.981 \mathrm{ppm}$ and $26.551 \mathrm{ppm}$, respectively.

Effect on the nutritional physiology of S. litura. The nutritional physiology of the larvae was also negatively affected in gallic acid treated larvae as evident from observations recorded for various nutritional indices (Table 3). The AD (approximate digestibility) of the larvae declined with treatment in comparison to control. The ECD (efficiency of conversion of digested food) and ECI (efficiency of conversion of ingested food) showed a significant concentration dependent decline. At the highest concentration of $3125 \mathrm{ppm}$ the ECD decreased by $56.69 \%$ and ECI decreased by $64.16 \%$ respectively when compared with control. The RGR (relative growth rate) and RCR (relative consumption rate) also decreased significantly in the larvae of $S$. litura with increasing concentration of gallic acid incorporated in diet. At 3125 ppm, a $87.88 \%$ reduction in RGR and $65.37 \%$ reduction in RCR was noticed as compared to control. The nutritional physiology of the larvae was more adversely affected when fed on azadirachtin treated diet when compared to control and gallic acid treated larvae (Table 4). 


\begin{tabular}{|l|l|l|l|l|l|}
\hline Concentrations $(\mathbf{p p m})$ & RGR $(\mathbf{m g} / \mathbf{m g} /$ day $)$ & RCR $(\mathbf{m g} / \mathbf{m g} /$ day $)$ & ECI $(\%)$ & ECD $(\%)$ & AD (\%) \\
\hline Control & $1.67 \pm 0.09^{\mathrm{a}}$ & $18.05 \pm 0.80^{\mathrm{a}}$ & $9.31 \pm 0.47^{\mathrm{a}}$ & $10.84 \pm 0.67^{\mathrm{a}}$ & $86.89 \pm 1.24^{\mathrm{a}}$ \\
\hline 5 & $0.92 \pm 0.06^{\mathrm{b}}$ & $13.79 \pm 0.64^{\mathrm{b}}$ & $6.85 \pm 0.32^{\mathrm{b}}$ & $8.32 \pm 0.38^{\mathrm{b}}$ & $82.99 \pm 2.27^{\mathrm{ab}}$ \\
\hline 25 & $0.70 \pm 0.04^{\mathrm{bc}}$ & $11.98 \pm 0.79^{\mathrm{bc}}$ & $6.02 \pm 0.43^{\mathrm{bc}}$ & $7.54 \pm 0.51^{\mathrm{bc}}$ & $80.51 \pm 2.28^{\mathrm{ab}}$ \\
\hline 125 & $0.51 \pm 0.03^{\mathrm{cd}}$ & $10.67 \pm 0.56^{\mathrm{c}}$ & $4.66 \pm 0.25^{\mathrm{cd}}$ & $6.58 \pm 0.44^{\mathrm{bcd}}$ & $72.46 \pm 3.03^{\mathrm{b}}$ \\
\hline 625 & $0.36 \pm 0.03^{\mathrm{de}}$ & $8.07 \pm 0.27^{\mathrm{d}}$ & $4.62 \pm 0.42^{\mathrm{cd}}$ & $6.11 \pm 0.48^{\mathrm{cd}}$ & $78.26 \pm 4.02^{\mathrm{ab}}$ \\
\hline 3125 & $0.20 \pm 0.02^{\mathrm{e}}$ & $6.26 \pm 0.20^{\mathrm{d}}$ & $3.34 \pm 0.69^{\mathrm{d}}$ & $4.69 \pm 0.39^{\mathrm{d}}$ & $77.27 \pm 2.43^{\mathrm{ab}}$ \\
\hline F-value & $102.53^{\star *}$ & $50.35^{\star *}$ & $32.47^{\star *}$ & $18.75^{\star *}$ & $3.69^{\star}$ \\
\hline
\end{tabular}

Table 3. Nutritional indices of $S$. litura when 6 days old instar larvae were fed on different concentrations of gallic acid. ${ }^{*}$ Significant at $1 \%,{ }^{\star}$ Significant at $5 \%$. Values are Mean \pm SE. Means followed by the same letter within the columns are not significantly different according to Tukey's test at $p \leq 0.05$.

\begin{tabular}{|l|l|l|l|l|l|}
\hline Concentrations $(\mathbf{p p m})$ & RGR $(\mathbf{m g} / \mathbf{m g} /$ day $)$ & RCR $(\mathbf{m g} / \mathbf{m g} /$ day) & ECI $(\%)$ & ECD (\%) & AD $(\%)$ \\
\hline Control & $1.67 \pm 0.09^{\mathrm{a}}$ & $18.05 \pm 0.80^{\mathrm{a}}$ & $9.31 \pm 0.47^{\mathrm{a}}$ & $10.84 \pm 0.70^{\mathrm{a}}$ & $86.89 \pm 1.24^{\mathrm{a}}$ \\
\hline 5 & $0.81 \pm 0.04^{\mathrm{b}}$ & $8.33 \pm 0.18^{\mathrm{b}}$ & $6.61 \pm 0.16^{\mathrm{b}}$ & $7.50 \pm 0.32^{\mathrm{b}}$ & $72.84 \pm 2.07^{\mathrm{b}}$ \\
\hline 25 & $0.58 \pm 0.01^{\mathrm{c}}$ & $7.74 \pm 0.11^{\mathrm{b}}$ & $5.10 \pm 0.23^{\mathrm{c}}$ & $6.21 \pm 0.31^{\mathrm{bc}}$ & $70.46 \pm 0.71^{\mathrm{b}}$ \\
\hline 125 & $0.38 \pm 0.02^{\mathrm{a}}$ & $7.14 \pm 0.20^{\mathrm{b}}$ & $3.92 \pm 0.21^{\mathrm{d}}$ & $4.47 \pm 0.40^{\mathrm{cd}}$ & $65.36 \pm 1.41^{\mathrm{bc}}$ \\
\hline 625 & $0.17 \pm 0.01^{\mathrm{e}}$ & $5.21 \pm 0.30^{\mathrm{c}}$ & $2.20 \pm 0.25^{\mathrm{e}}$ & $3.90 \pm 0.28^{\mathrm{d}}$ & $60.38 \pm 3.45^{\mathrm{cd}}$ \\
\hline 3125 & $0.10 \pm 0.01^{\mathrm{e}}$ & $4.27 \pm 0.35^{\mathrm{c}}$ & $1.86 \pm 0.19^{\mathrm{e}}$ & $3.30 \pm 0.38^{\mathrm{d}}$ & $56.20 \pm 2.59^{\mathrm{d}}$ \\
\hline F-value & $172.97^{* *}$ & $186.37^{* *}$ & $107.80^{* *}$ & $46.02^{* *}$ & $26.12^{* *}$ \\
\hline
\end{tabular}

Table 4. Nutritional indices of S. litura when 6 days old instar larvae were fed on different concentrations of azadirachtin. ${ }^{*}$ Significant at $1 \%$. Values are Mean \pm SE. Means followed by the same letter within the columns are not significantly different according to Tukey's test at $p \leq 0.05$.

\begin{tabular}{|l|l|l|l|l|l|}
\hline Concentrations (ppm) & $\mathbf{2 4} \mathbf{h}$ & $\mathbf{4 8} \mathbf{~ h}$ & $\mathbf{7 2} \mathbf{h}$ & $\mathbf{9 6} \mathbf{~ h}$ & $\mathbf{1 2 0} \mathbf{~ h}$ \\
\hline Control & $1.25 \pm 0.11^{\mathrm{a}}$ & $1.83 \pm 0.26^{\mathrm{a}}$ & $1.67 \pm 0.10^{\mathrm{a}}$ & $1.92 \pm 0.15^{\mathrm{a}}$ & $2.58 \pm 0.24^{\mathrm{a}}$ \\
\hline $\mathrm{LC}_{30}(52.44)$ & $7.17 \pm 0.28^{\mathrm{b}}$ & $8.25 \pm 0.28^{\mathrm{b}}$ & $13.08 \pm 0.86^{\mathrm{b}}$ & $15.58 \pm 0.51^{\mathrm{b}}$ & $23.67 \pm 0.28^{\mathrm{b}}$ \\
\hline $\mathrm{LC}_{50}(402.80)$ & $14.58 \pm 0.20^{\mathrm{c}}$ & $19.67 \pm 0.40^{\mathrm{c}}$ & $24.58 \pm 1.59^{\mathrm{c}}$ & $29.50 \pm 0.48^{\mathrm{c}}$ & $45.25 \pm 0.44^{\mathrm{c}}$ \\
\hline F-value & $1025.59^{* *}$ & $973.67^{* *}$ & $705.46^{* *}$ & $1110.45^{* *}$ & $4130.61^{* *}$ \\
\hline
\end{tabular}

Table 5. Hemocyte deformities (\%) in S. litura larvae under the influence of gallic acid. ${ }^{*}$ Significant at $1 \%$. Values are Mean \pm SE. Means followed by different superscript letters within a column are significantly different $(p \leq 0.05)$ based on Tukey's test.

Effect of gallic acid on the cellular immune response of S. litura. At all treatment intervals the percent hemocyte deformity increased significantly and was maximum in larvae fed on $\mathrm{LC}_{50}$ concentration when compared with control (Table 5). Hemocytes deformities were observed in the form of clustering, necrosis and vacuolization of hemocytes (Figs. 1, 2). The total haemocyte count in larvae fed on diet amended with $\mathrm{LC}_{50}$ and $\mathrm{LC}_{30}$ concentration of the gallic acid also significantly declined at all the treatment intervals when compared with control (Table 6).

Quantitative real time PCR (qrt-PCR) assay on S. litura larvae. Gene expression of Superoxide Dismutase (SOD), Esterase (EST), GST (Glutathione S- transferase), Glutathione peroxidase (GPOX) and Peroxidase (POX) increased significantly in 3rd instar larvae of S. litura fed on gallic acid at 48 and $72 \mathrm{~h}$ treatment intervals with respect to control. Esterase, SOD, GST and POX expression showed maximum increase at $48 \mathrm{~h}$ interval. Gene expression of Glutathione peroxidase at $48 \mathrm{~h}$ interval showed a 4.23 fold increase as compared to control but declined at $72 \mathrm{~h}$ interval (Fig. 3).

Effect on B. hebetor adults. Gallic acid showed no significant effect on female fecundity, percent parasitization and the eggs laid per host at both $\mathrm{LC}_{50}$ and $\mathrm{LC}_{30}$ concentrations when compared to control (Table 7).

Effect on the growth and development of $B$. hebetor. The percent hatching and percent adult emergence of $B$. hebetor larvae declined significantly on $S$. litura larvae treated with $\mathrm{LC}_{50}$ and $\mathrm{LC}_{30}$ concentration of the phenolic acid. The decline in hatching and adult emergence was noticeably greater at $\mathrm{LC}_{50}$ then at $\mathrm{LC}_{30} \mathrm{~A}$ $23 \%$ reduction in hatching was observed at $\mathrm{LC}_{50}$ whereas only $10 \%$ decrease in hatching at $\mathrm{LC}_{30}$ concentration was observed when compared to control but increase in hatching and adult emergence was observed when 


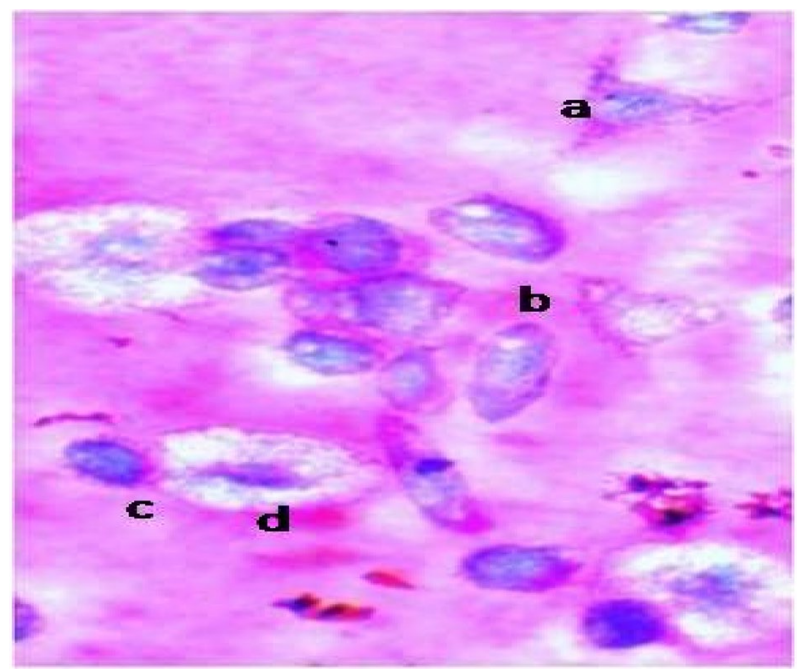

Figure 1. (a, b) Normal plasmatocytes (c) Normal granulocyte (d) Normal spherulocyte.

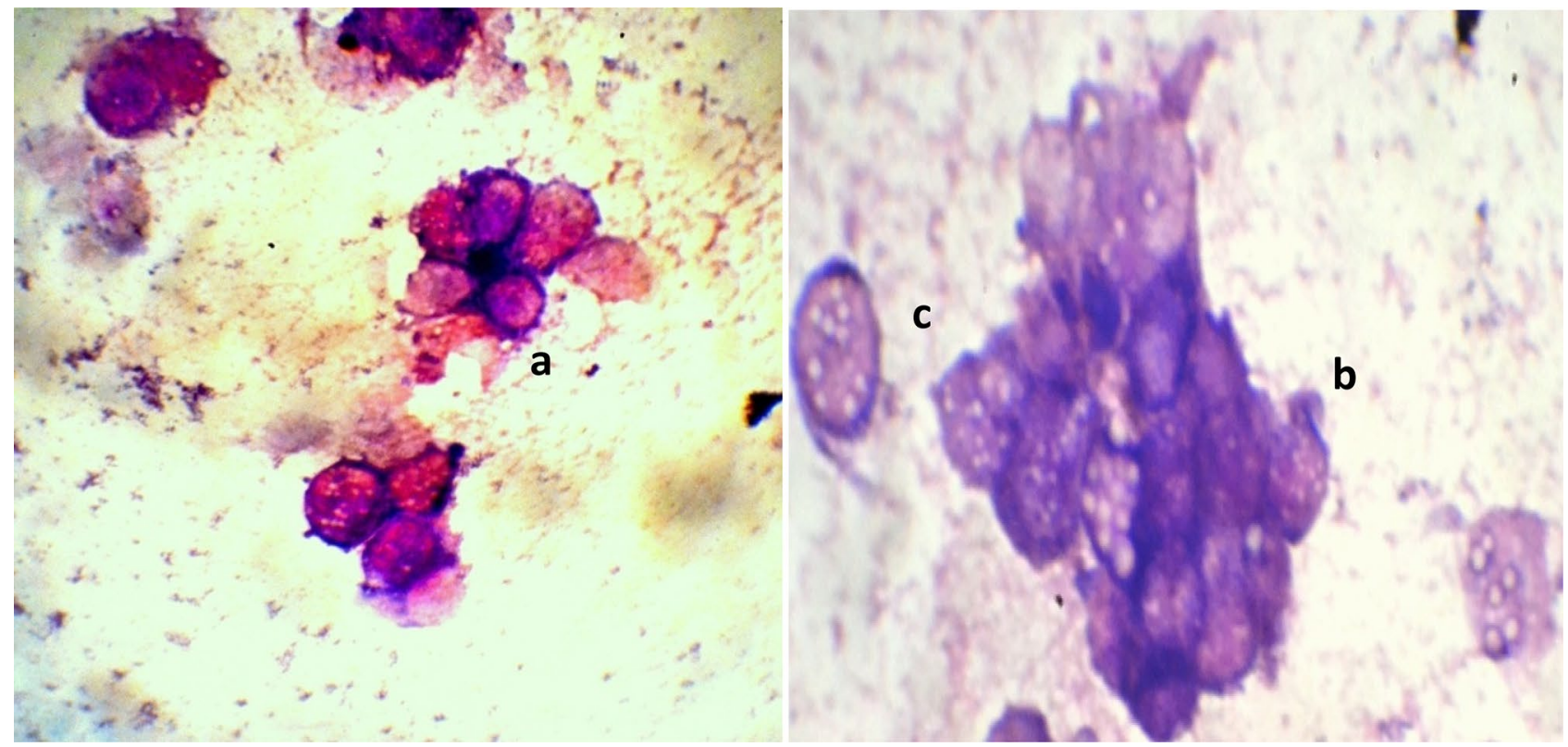

Figure 2. (a) Necrosis (b) Clustering (c) Vacuolization of hemocytes.

\begin{tabular}{|l|l|l|l|l|l|}
\hline Concentrations (ppm) & $\mathbf{2 4} \mathbf{h}$ & $\mathbf{4 8} \mathbf{h}$ & $\mathbf{7 2} \mathbf{h}$ & $\mathbf{9 6} \mathbf{h}$ & $\mathbf{1 2 0} \mathbf{h}$ \\
\hline Control & $9533.3 \pm 84.30^{\mathrm{a}}$ & $9766.7 \pm 61.50^{\mathrm{a}}$ & $10,467 \pm 84.30^{\mathrm{a}}$ & $11,267 \pm 66.70^{\mathrm{a}}$ & $11,400 \pm 61.70^{\mathrm{a}}$ \\
\hline $\mathrm{LC}_{30}(52.44)$ & $9166.7 \pm 61.50^{\mathrm{b}}$ & $8366.7 \pm 80.30^{\mathrm{b}}$ & $8266.7 \pm 42.20^{\mathrm{b}}$ & $7633 \pm 120.00^{\mathrm{b}}$ & $7533 \pm 66.70^{\mathrm{b}}$ \\
\hline $\mathrm{LC}_{50}(402.80)$ & $8733.3 \pm 66.70^{\mathrm{c}}$ & $7400.0 \pm 51.60^{\mathrm{c}}$ & $7266.7 \pm 42.20^{\mathrm{c}}$ & $7000 \pm 89.40^{\mathrm{c}}$ & $6766.7 \pm 61.50^{\mathrm{c}}$ \\
\hline F-value & $31.38^{\star \star}$ & $329.57^{\star \star}$ & $753.75^{\star \star}$ & $591.45^{\star \star}$ & $1365^{\star \star}$ \\
\hline
\end{tabular}

Table 6. Effect of gallic acid on total hemocyte count (Total number of hemocytes $/ \mathrm{mm}^{3}$ ) of $S$. litura larvae. ${ }^{*}$ Significant at $1 \%$. Values are Mean \pm SE. Means followed by different superscript letters within a column are significantly different $(p \leq 0.05)$ based on Tukey’s test. 

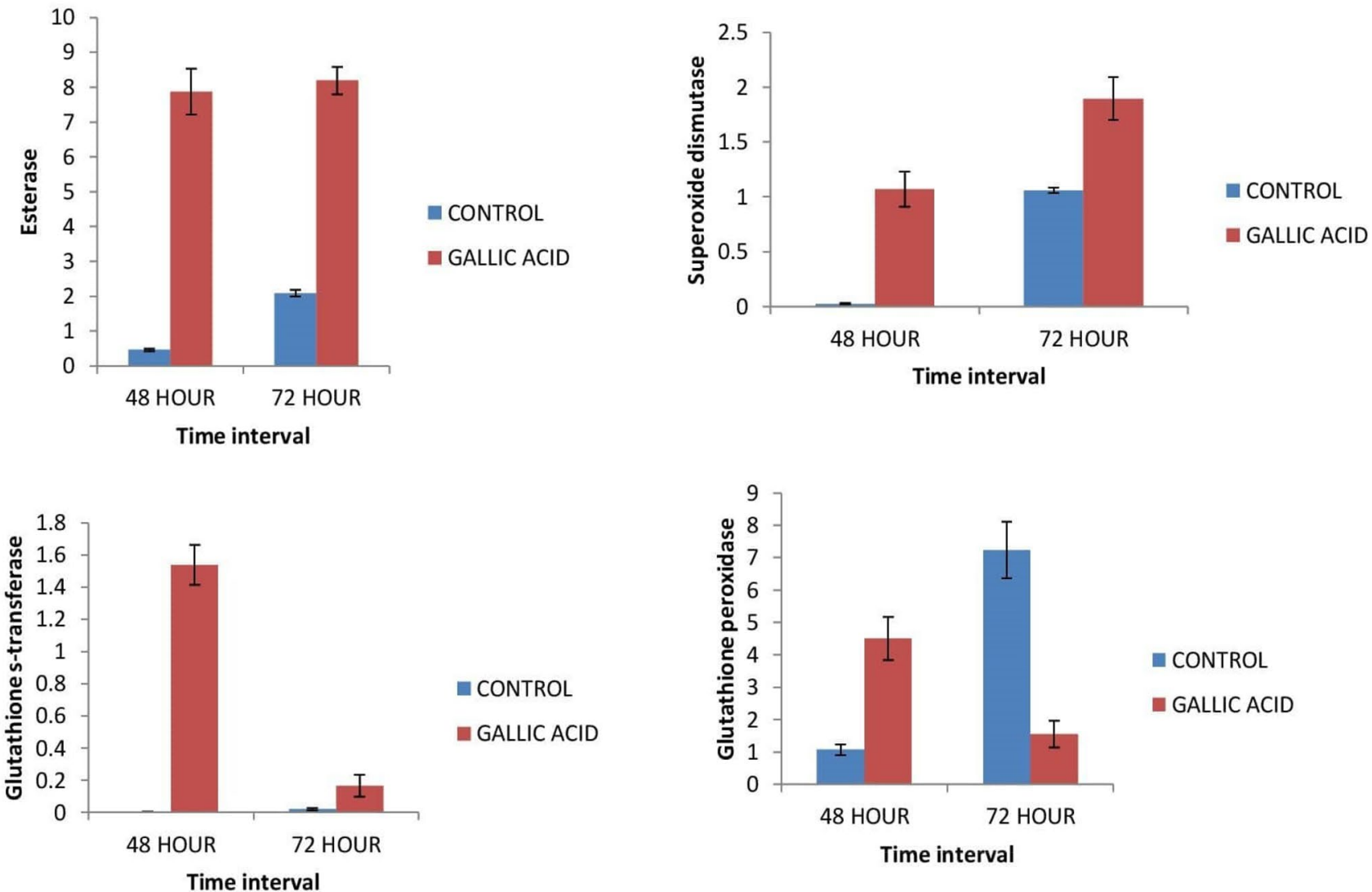

CONTROL

- GALLIC ACID

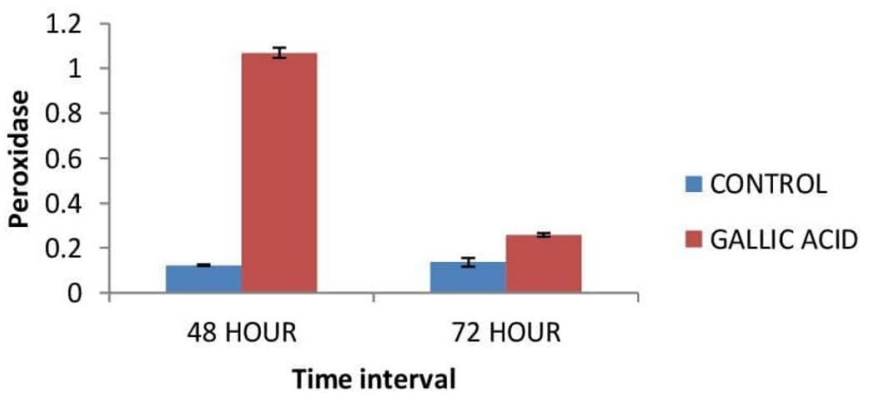

Figure 3. Effect on the expression (Means \pm S.E) of different antioxidant genes (EST, SOD, GST, GPOX and POX) of $S$. litura larvae treated with artificial diet amended with and without gallic acid.

\begin{tabular}{|l|l|l|l|}
\hline Concentrations $(\mathbf{p p m})$ & Parasitization (\%) & Eggs per host & Fecundity (\%) \\
\hline Control & $80.00 \pm 7.75^{\mathrm{a}}$ & $12.12 \pm 0.72^{\mathrm{a}}$ & $45.83 \pm 4.26^{\mathrm{a}}$ \\
\hline$(\mathrm{GA}) \mathrm{LC}_{30}(52.44)$ & $76.76 \pm 2.71^{\mathrm{a}}$ & $11.67 \pm 2.33^{\mathrm{a}}$ & $36.75 \pm 9.41^{\mathrm{a}}$ \\
\hline$(\mathrm{GA}) \mathrm{LC}_{50}(402.80)$ & $60.00 \pm 6.83^{\mathrm{a}}$ & $9.16 \pm 0.77^{\mathrm{a}}$ & $30.33 \pm 3.87^{\mathrm{a}}$ \\
\hline$(\mathrm{AZA}) \mathrm{LC}_{30}(5.981)$ & $25.00 \pm 2.24^{\mathrm{b}}$ & $4.18 \pm 0.25^{\mathrm{b}}$ & $8.25 \pm 1.03^{\mathrm{b}}$ \\
\hline$(\mathrm{AZA}) \mathrm{LC}_{50}(26.551)$ & $15.00 \pm 2.22^{\mathrm{b}}$ & $1.62 \pm 0.26^{\mathrm{b}}$ & $4.42 \pm 0.51^{\mathrm{b}}$ \\
\hline F-value & $36.67^{\star *}$ & $16.29^{\star *}$ & $13.25^{\star *}$ \\
\hline
\end{tabular}

Table 7. Parasitization, no. of parasitized egg/host and fecundity of B. hebetor adults reared on S. litura larvae fed on gallic acid and azadirachtin supplemented diet. ${ }^{* *}$ Significant at $1 \%$. Values are Mean \pm SE. Means followed by the same letter within the columns are not significantly different according to Tukey's test at $p \leq 0.05$. GA (Gallic acid), AZA (Azadirachtin). 


\begin{tabular}{|l|l|l|l|l|l|l|l|}
\hline $\begin{array}{l}\text { Concentrations } \\
(\mathbf{p p m})\end{array}$ & Hatching (\%) & Larval mortality (\%) & Larval period (days) & $\begin{array}{l}\text { Cocoon period } \\
(\text { days) }\end{array}$ & $\begin{array}{l}\text { Total development } \\
\text { period (days) }\end{array}$ & $\begin{array}{l}\text { Adult emergence } \\
(\%)\end{array}$ & $\begin{array}{l}\text { Female emergence } \\
(\%)\end{array}$ \\
\hline Control & $92.85 \pm 0.91^{\mathrm{a}}$ & $11.34 \pm 1.99^{\mathrm{a}}$ & $4.70 \pm 0.07^{\mathrm{a}}$ & $5.89 \pm 0.07^{\mathrm{a}}$ & $11.49 \pm 0.09^{\mathrm{a}}$ & $92.93 \pm 1.58^{\mathrm{a}}$ & $62.14 \pm 4.40^{\mathrm{a}}$ \\
\hline$(\mathrm{GA}) \mathrm{LC}_{30}(52.44)$ & $83.37 \pm 3.01^{\mathrm{ab}}$ & $17.83 \pm 4.38^{\mathrm{ab}}$ & $4.71 \pm 0.16^{\mathrm{a}}$ & $5.91 \pm 0.30^{\mathrm{a}}$ & $11.63 \pm 0.16^{\mathrm{a}}$ & $80.37 \pm 3.68^{\mathrm{a}}$ & $56.31 \pm 4.95^{\mathrm{ab}}$ \\
\hline$(\mathrm{GA}) \mathrm{LC}_{50}(402.80)$ & $71.49 \pm 5.77^{\mathrm{b}}$ & $30.48 \pm 3.55^{\mathrm{b}}$ & $4.92 \pm 0.05^{\mathrm{a}}$ & $6.40 \pm 0.09^{\mathrm{a}}$ & $12.70 \pm 0.09^{\mathrm{b}}$ & $61.01 \pm 4.35^{\mathrm{b}}$ & $36.53 \pm 7.87^{\mathrm{bc}}$ \\
\hline$(\mathrm{AZA}) \mathrm{LC}_{30}(5.981)$ & $39.92 \pm 2.08^{\mathrm{c}}$ & $49.58 \pm 2.11^{\mathrm{c}}$ & $6.33 \pm 0.21^{\mathrm{b}}$ & $7.50 \pm 0.22^{\mathrm{b}}$ & $14.04 \pm 0.26^{\mathrm{c}}$ & $39.84 \pm 3.42^{\mathrm{c}}$ & $36.62 \pm 4.26^{\mathrm{bc}}$ \\
\hline$(\mathrm{AZA}) \mathrm{LC}_{50}(26.551)$ & $27.27 \pm 2.16^{\mathrm{c}}$ & $72.70 \pm 1.80^{\mathrm{d}}$ & $7.00 \pm 0.36^{\mathrm{b}}$ & $7.96 \pm 0.26^{\mathrm{b}}$ & $15.71 \pm 0.19^{\mathrm{d}}$ & $29.30 \pm 1.78^{\mathrm{c}}$ & $20.19 \pm 2.56^{\mathrm{c}}$ \\
\hline F-value & $76.43^{\star \star}$ & $71.94^{\star \star}$ & $27.31^{\star \star}$ & $19.86^{\star \star}$ & $107.07^{\star \star}$ & $74.40^{\star \star}$ & $10.96^{\star \star}$ \\
\hline
\end{tabular}

Table 8. Development and survival of $B$. hebetor larvae emerged from S. litura larvae fed on gallic acid and azadirachtin supplemented diet. ${ }^{*}$ Significant at $1 \%$, ${ }^{\star}$ Significant at $5 \%,{ }^{\text {ns }}$ Non significant. Values are Mean \pm SE. Means followed by the same letter within the columns are not significantly different according to Tukey's test at $p \leq 0.05$.GA (Gallic acid), AZA (Azadirachtin).

compared with azadirachtin treated larvae. Similarly, the adult emergence was reduced to $34.33 \%$ at $\mathrm{LC}_{50}$ but at lower concentration of $\mathrm{LC}_{30}$, it was reduced by only $13.52 \%$ as compared to control. The inhibition in female emergence was also greater at $\mathrm{LC}_{50}$ than at $\mathrm{LC}_{30}$ but when compared to positive control an increase in emergence was observed. The larval period and the pupal period were not significantly affected at both the concentrations when compared with control but significant increase in total development period was observed with increase in concentration from $\mathrm{LC}_{30}$ to $\mathrm{LC}_{50}$ concentration of gallic acid provided to the host with respect to control. Azadirachtin treated $S$. ltura larvae had more significant adverse affect on growth and survival of $B$. hebetor at both $\mathrm{LC}_{30}$ and $\mathrm{LC}_{50}$ when compared with gallic acid fed larvae. Azadirachtin was found to have more toxic effect at third trophic level (Table 8).

\section{Discussion}

The artificial diet containing gallic acid when fed to 6 days old S. litura larvae had negative effects on the larvae as well as on its parasitoid, $B$. hebetor. The larval mortality increased and adult emergence decreased under the influence of gallic acid in a concentration dependent manner. Selim-Rani et al. ${ }^{21}$ had also reported that quercetin isolated from Euphorbia hirta L. caused mortality and cellular deformities in second, fourth and fifth instar larvae of S. litura. Ghumare and Mukherjee ${ }^{22}$ had reported that $S$. litura larvae develop better on plants having lower phenolic content. Ananthakrishnan et al. ${ }^{23}$ had also reported the excessive defecation along with formation of muscular lesions in the posterior half of the $S$. litura larvae after consumption of gallic acid supplemented diet. Prolonged larval and total developmental period of S. litura larvae was also noticed. Inability of S. litura larvae to develop on artificial diet containing phenolic rich extracts of red gram (Cajanus cajan L.) and Acacia nilotica (L.) has been reported by Bhattacharya and Chenchiah ${ }^{24}$ and by Gautam et al. ${ }^{25}$, respectively. Gallic acid, hydrolysable tannin can interact with metal ions and macromolecules such as polysaccharides. It can also form soluble complexes with proteins and can inhibit digestive enzymes and is thus toxic to insects ${ }^{26}$.

The nutritional indices were reduced significantly with increase in concentration of gallic acid. Ingestion of gallic acid incorporated diet decreased with a consistent decrease in RGR of S. litura larvae. Gallic acid seems to have inhibited growth by either exerting an antifeedant or toxic effect on the S. litura larvae. Both ECI and ECD declined with increase in concentration of gallic acid. The decrease in ECD and ECI of S. litura larvae reflect increased metabolic cost which might have occurred due to the energy required for detoxification of the compound. These findings indicate toxicity of gallic acid to S. litura larvae was due to the inhibitory effect on digestion and reduced efficiency of conversion of assimilated food into biomass. Toxic effects of gallic acid have also been reported against other insects such as melon fruit fly, Bactrocera cucurbitae (Coquillett) larvae ${ }^{27}$. Our findings indicated that azadirachtin incorporated diet was more toxic to S. litura as compared to gallic acid incorporated diet. The toxic effects of azadirachtin on feeding and mortality of S. litura was also reported by Nathan and Kalaivani ${ }^{28}$ and Deota and Upadhyay ${ }^{29}$. Azadirachtin induced structural changes in the S. litura larval midgut by activation of apoptosis ${ }^{30}$.

Studies on tritrophic interactions involving plants, insects and their parasitoids have made significant contribution towards understanding the role of plant traits such as induced volatiles on host location and acceptance behavior by natural insect enemies ${ }^{31}$. However, reports linking plant allelochemicals and parasitoids are very few. Most of these reports have highlighted the adverse effects of plant allelochemicals on parasitoid development. Camphell and Duffey ${ }^{32,33}$ had reported higher mortality rates, morphological deformities, increased development time, decreased adult weight and longevity of Hyposoter exiguae (Viereck) developing in caterpillars of tomato fruitworm, Heliothis zea (Boddie) fed on artificial diet containing a tomatine, a glycol alkaloid as compared to those fed on control diet. Rutin, a phenolic compound also exerted indirect negative effects on H. exigua fed on treated H. armigera $^{34}$. Linear furanocoumarin too was reported to increase larval mortality of the host S. exigua and its parasitoid Archytas marmoratus (Townsend) ${ }^{8}$. Corroboratory results were obtained for the parasitoid, $B$. hebetor when it was allowed to parasitize S. litura larvae which had been fed gallic acid incorporated diet. However, it was noticed that these effects were significantly greater at higher concentration of gallic acid $\left(\mathrm{LC}_{50}\right)$ than at lower concentration $\left(\mathrm{LC}_{30}\right)$ when compared to control. Larval mortality of $B$. hebetor larvae increased and adult emergence decreased as the concentration of gallic acid supplemented in diet of $S$. litura larvae increased from $\mathrm{LC}_{30}$ to $\mathrm{LC}_{50}$. While the larval period and pupal period of $B$. hebetor larvae was not significantly affected, the time taken by the larvae to develop into adults also showed a concentration dependent increase. These findings 
indicated that toxicity of gallic acid to $S$. litura as well as its parasitoid increased with increase in concentration. Similar to our findings, El-Heneidy et al. ${ }^{35}$ had reported that high levels of nicotine in artificial diet of $S$. frugiperda (JE smith) lowered the survival rate of larvae of its parasitoid, Hyposter annulipas (Coresson), prolonged the developmental time and resulted in small sized adults. Reitz and Trumble ${ }^{36}$ had also observed that fewer adults of parasitoid, Copidosonma floridarum (Ashmead) emerged from broods developing on cabbage looper, Trichoplusia ni (Hubner) fed on artificial diet containing higher concentration of three furanocoumarins viz., psoralen, xanthotoxin and bergapten when compared to diet having lower furanocoumarin concentrations.

Gallic acid also affected the hatching of $B$. hebetor larvae which was considerably less in S. litura larvae fed $\mathrm{LC}_{50}$ concentration than at $\mathrm{LC}_{30}$ concentration when compared to control. Mondy et al. ${ }^{37}$ had observed that nutrients obtained from host affect egg viability and hatching in parasitoids. S. litura larvae feeding on diet having higher levels of gallic acid may have been a poor quality host which could have been due to diversion of energy and resources to detoxify the phenolic acid or could have resulted from gallic acid toxicity. Punia et al. ${ }^{38}$ also reported deterrence of host quality under the influence of ellagic acid which indirectly impacted the survival of its parasitoid, B. hebetor. Barbosa and Saunders ${ }^{39}$ had reported that toxic substances in plants retard growth, reduce vigour or kill susceptible herbivores and can cause physiological or metabolic changes in parasitoids.

Increasing concentration of gallic acid provided to $S$. litura larvae decreased parasitization by $B$. hebetor adults. The eggs laid per host as well as fecundity of $B$. hebetor adults decreased in the treated larvae. However the decrease was not significant. Furanocoumarins viz., isopimpinellin and xanthotoxin were also found to decrease the parasitization rate and clutch size of both male and female of polyembryonic parasitoid, Copidosoma sosares (Walker) when reared on hosts fed on higher concentrations of the compounds ${ }^{40}$.

Growth inhibitory effects of gallic acid were less severe on parasitoid when compared to positive control (azadirachtin). The toxic effect of azadirachtin on larval stages and adult emergence of Trichogramma chilonis Ishii was also reported by Narendra et al. $^{41}$. Commercial formulations of azadirachtin had also been reported to negatively affect the life table parameters of Habrobracon hebetor (Say) by Abedi et al. ${ }^{42}$. Our findings showed 93.33\% mortality of S. litura larvae at higher concentration of azadirachtin. In field conditions this may indirectly affect the survival of natural enemies as the mortality of prey population is high. This would result in reduction of food source for natural enemies and thus lead to decline in natural enemy population through starvation ${ }^{43,44}$.

Hemocytes form an important component of immune system in insects. Plant metabolites can impact parasitoid survival by altering the immune response of insects ${ }^{45}$. In the present study a significant decline in total hemocyte count and increase in hemocyte deformity was observed in S. litura larvae when fed on gallic acid treated diet when compared with control. Similarly, Ayyangar and $\mathrm{RaO}^{46}$ had also reported significant decline in total haemocyte count in the haemolymph of final instar larvae of S. litura when treated with azadirachtin. Zibaee and Bandani ${ }^{47}$ had also reported a significant dose dependent decline in total hemocyte count of adults of sunn pest, Eurygaster integriceps (Puton) when fed on diet containing Artemisia annua extract. Crude aqueous leaf extract of $C$. inerme had also resulted in lower haemocyte count in the 6th instar larvae of the cotton bollworm, Helicoverpa armigera (Hubner) ${ }^{48}$. Plumbagin, a phytochemical, was also found to drastically reduce the haemocytes of red cotton bug, Dysdercus koenigii (F. $)^{49}$. The findings indicate that feeding on gallic acid incorporated diet compromised the cellular immune response of S. litura larvae and thereby increased its susceptibility to attack by the parasitoid.

Oxidation of phenolic compounds generate free radicals which can affect the growth and survival of insect $^{50,51}$. Upregulated expression of genes for the antioxidant enzymes, SOD, Glutathione peroxidae and POX indicate their involvement in mitigating oxidative stress in the larvae generated by the ingestion of gallic acid incorporated diet. Also the expression of the genes encoding esterases and GSTs increased in S. litura larvae with treatment. Insects show resistance to allelochemicals via short term induction of detoxification enzymes ${ }^{52}$. The involvement of the GST super family in the detoxification of various plant xenobiotics has been reported by Ref..$^{53}$. Various xenobiotics and endogenous compounds, including insecticides, drugs, insect hormones, organic solvents, allelochemicals and host plants lead to the induction of detoxification enzymes viz., glutathione transferases and esterases ${ }^{54}$. Li et al. ${ }^{55}$ also reported the involvement of esterase in allelochemical metabolism.

It can be concluded from the present findings that gallic acid at lower concentrations impaired the growth of $S$. litura but only slightly affected the development of $B$. hebetor. However higher concentrations of gallic acid were toxic to both the host as well as its parasitoid. This study could provide baseline data to plant breeders for enhancing resistance traits in plants against insect pests without causing any significant harm to their parasitoids.

\section{Methods}

The cultures of S. litura, B. hebetor and rice moth, Corcyra cephalonica (Stainton) were maintained in the laboratory at standard conditions of $25 \pm 2{ }^{\circ} \mathrm{C}$ temperature, $65 \pm 5 \%$ relative humidity (RH) and 12:12 (D:L) photoperiod.

Spodoptera litura rearing. The S. litura were reared on fresh castor leaves, Ricinus communis (L.) under standard conditions in the Insect Physiology laboratory of Guru Nanak Dev University, Amritsar. The glass jars $(15 \mathrm{~cm} \times 10 \mathrm{~cm})$ having fresh castor leaves, $R$. communis were used for culturing until pupation. On pupation, the pupae were transferred to pupation jars $(15 \mathrm{~cm} \times 10 \mathrm{~cm})$ which had $4-5 \mathrm{~cm}$ of moist sand covered with filter paper. On emergence, the adults were shifted to oviposition jars $(15 \mathrm{~cm} \times 10 \mathrm{~cm})$ lined with filter paper to facilitate egg laying, secured with muslin cloth to check their escape and provided with cotton swab soaked with water and honey solution $(4: 1)$ to serve as food.

Bracon hebetor rearing. The parasitoid, B. hebetor was reared on 5th instar larvae of C. cephalonica. The culture of $C$. cephalonica was reared on partially crushed sorghum grains at standard conditions of temperature $\left(25 \pm 2{ }^{\circ} \mathrm{C}\right)$ and humidity $(65 \pm 5 \% \mathrm{RH})$. The freshly emerged adult parasitoids in ratio 1:2 (male:female) were 
transferred to glass chimneys having a cotton swab soaked in water and honey (4:1) solution to serve as food. The parasitoid, $B$. hebetor was provided with healthy 5 th instar larvae of $C$. cephalonica for parasitization and parasitized larvae were observed for egg laying under microscope and were then kept inside tissue papers in plastic petri plates $(90 \mathrm{~mm} \times 15 \mathrm{~mm}$ ) until cocoon formation. The cocoons formed were shifted into sterile solo cups $(4 \mathrm{~cm} \times 6 \mathrm{~cm})$ and the adults emerged were allowed to mate for $24 \mathrm{~h}$. These newly emerged $B$. hebetor larvae were then used for bioassay studies.

Chemicals used. Gallic acid and azadirachtin with 95\% purity were obtained from Sigma Aldrich Pvt. Ltd., India.

Conduction of experiment. Bioassays with S. litura. To evaluate the effect of gallic acid on S. litura and its parasitoid, stock solution having concentration $15625 \mathrm{ppm}$ was prepared in distilled water and added in artificial diet of the insect in amounts required to have the desired concentrations i.e. 5, 25, 125, 625 and $3125 \mathrm{ppm}$. Diet without gallic acid was taken as control. These concentrations were delivered to the insect when it fed on the diet. Azadirachtin incorporated diet with different concentrations i.e. 5, 25, 125, 625 and 3125 ppm was taken as positive control. The antibiosis effect of gallic acid on S. litura was ascertained by feeding the six days old larvae on diet supplemented with 5, 25, 125, 625 and $3125 \mathrm{ppm}$ of the compound. The larvae were kept in sterilized plastic containers containing treated and control diet and were examined daily for different parameters viz., the larval period, total development period, larval mortality, pupal weight and adult emergence. The $\mathrm{LC}_{30}$ and $\mathrm{LC}_{50}$ concentrations were ascertained from the data obtained. The experiments had six replicates with five larvae in each replicate and the experiments were repeated twice.

Nutritional assays with S. litura. A 3 days experiment was conducted with 6 days old larvae of S. litura according to Koul et al. ${ }^{56}$ using different concentrations of gallic acid and azadirachtin (5 ppm, $25 \mathrm{ppm}, 125 \mathrm{ppm}$, $625 \mathrm{ppm}$ and $3125 \mathrm{ppm}$ ) along with control. The larvae were weighed and released into sterilized plastic container already containing weighed treated and control diet. The larvae were allowed to feed for $72 \mathrm{~h}$ and then annotations were made for final larval weight, diet left and fecal matter (in $\mathrm{mg}$ ) and the dry weights for the same were taken after incubating for $72 \mathrm{~h}$ at $60^{\circ} \mathrm{C}$ inside an incubator. The dry weight readings served the purpose of water loss under controlled conditions. From this data, the following nutritional indices were calculated on dry weight basis after 3 days of feeding as proposed by Waldbauer ${ }^{57}$. Each concentration including control was replicated 6 times with 5 larvae in each replicate and the experiment was repeated twice.

$$
\begin{gathered}
\mathrm{RGR}=\frac{\text { Change in larval dry weight/day }}{\text { Initial larval dry weight }} \\
\mathrm{RCR}=\frac{\text { Change in diet dry weight/day }}{\text { Initial larval dry weight }} \\
\mathrm{ECDI}=\frac{\text { Dry weight gain of insect }}{\text { Dry weight of food ingested }} \times 100 \\
\mathrm{AD}=\frac{\text { Dry weight gain of insect }- \text { Dry weight of frass }}{\text { Dry weight of food ingested }- \text { Dry weight of frass }} \times 100
\end{gathered}
$$

where RGR = Relative growth rate, $\mathrm{RCR}=$ Relative consumption rate, ECI = Efficiency of conversion of ingested food, $\mathrm{ECD}=$ Efficiency of conversion of digested food, $\mathrm{AD}=$ Approximate digestibility.

Bioassays with $B$. hebetor. The effect of gallic acid and azadirachtin on parasitization and fecundity of $B$. hebetor was studied by allowing the newly emerged adults to mate for $24 \mathrm{~h}$ and the mated adults were then transferred to glass chimney in the ratio female: male (2:1). The rearing of S. litura larvae upto 3 rd instar stage was done on diet amended with $\mathrm{LC}_{30}$ and $\mathrm{LC}_{50}$ concentrations of gallic acid as well as on control (unamended diet). A single treated 12 days old $S$. litura larvae was then exposed to parasitoid wasp for $24 \mathrm{~h}$ in the chimney and then the parasitized larvae were transferred on tissue paper in the petriplates $(90 \mathrm{~mm} \times 14 \mathrm{~mm})$. The paralyzed larvae were observed daily under stereo microscope (Magnus) at 40X magnification to observe parasitoid eggs for various parameters. In this way, $S$. litura larvae fed on different concentrations of gallic acid in artificial diet were exposed daily till the female died in each treatment.

Effect of gallic acid and azadirachtin on the development of $\boldsymbol{B}$. hebetor. The effect of gallic acid and azadirachtin on development of $B$. hebetor was evaluated by taking two days old mated females in glass chimneys (two wasps per chimney). The females were allowed to oviposit on the larvae of $S$. litura (3rd instar) reared on artificial diet amended with $\mathrm{LC}_{30}$ and $\mathrm{LC}_{50}$ concentration of gallic acid. The treated larvae of $S$. litura were provided to parasitoid wasps for $24 \mathrm{~h}$. The parasitized $S$. litura larvae were removed from the chimneys and 


\begin{tabular}{|c|c|c|c|c|}
\hline Gene name & Primer sequence & Annealing temperature & Product size & GenBank accession number \\
\hline \multirow{2}{*}{ Actin } & $\begin{array}{l}\text { Forward primer 5'TGCGTGACATCAAGG } \\
\text { AGAAG } 3^{\prime}\end{array}$ & 52 & \multirow{2}{*}{191} & \multirow{2}{*}{ XM_022975383.1 } \\
\hline & $\begin{array}{l}\text { Reverse Primer 5'GCAAGCTTCCATACC } \\
\text { CAAGA3' }\end{array}$ & 52 & & \\
\hline \multirow{2}{*}{ SOD } & $\begin{array}{l}\text { Forward primer 5'GGCAAAGGGGCTACA } \\
\text { TGTCT3' }\end{array}$ & 54 & \multirow{2}{*}{188} & \multirow{2}{*}{ XM_022958483.1 } \\
\hline & $\begin{array}{l}\text { Reverse primer 5'ATACGTTTCCGAGGT } \\
\text { CACCG3' }\end{array}$ & 54 & & \\
\hline \multirow{2}{*}{ EST } & $\begin{array}{l}\text { Forward primer 5'TGCAATGCTTTGGGC } \\
\text { AACTAA3' } \\
\end{array}$ & 50 & \multirow{2}{*}{191} & \multirow{2}{*}{ XM_022972575.1 } \\
\hline & $\begin{array}{l}\text { Reverse primer 5'TCGCTTTTGATTCATCTG } \\
\text { GTTGTC3' }\end{array}$ & 54 & & \\
\hline \multirow{2}{*}{ GST } & $\begin{array}{l}\text { Forward primer 5'TTACTTTGGAGGGCA } \\
\text { TCGTC3' }\end{array}$ & 50 & \multirow{2}{*}{190} & \multirow{2}{*}{ KF482978.1 } \\
\hline & $\begin{array}{l}\text { Reverse primer 5'TTGTGGTGAGTTCGC } \\
\text { ATGTT3' }\end{array}$ & 50 & & \\
\hline \multirow{2}{*}{ POX } & $\begin{array}{l}\text { Forward primer 5'TACTGACGGTCATGC } \\
\text { ACACT3' }\end{array}$ & 53 & \multirow{2}{*}{229} & \multirow{2}{*}{ XM_022970394.1 } \\
\hline & $\begin{array}{l}\text { Reverse primer 5'CCGTCCCAGTAACCC } \\
\text { TCTTT3' }\end{array}$ & 53 & & \\
\hline \multirow{2}{*}{ GPOX } & $\begin{array}{l}\text { Forward primer 5'AAAGCTGCGACATCC } \\
\text { ATCCA3' }\end{array}$ & 52 & \multirow{2}{*}{175} & \multirow{2}{*}{ XM_022972377.1 } \\
\hline & $\begin{array}{l}\text { Reverse primer 5'TGTCCTCGGCATATTTCT } \\
\text { CGT3' }^{\prime}\end{array}$ & 52 & & \\
\hline
\end{tabular}

Table 9. Primer sequences used for gene expression analysis using qRT-PCR.

fresh hosts were provided to the wasps daily. The larvae removed from the chimney were placed individually in petri plates $(90 \mathrm{~mm} \times 14 \mathrm{~mm})$ and were allowed to complete development. The petri plates were checked daily for development of parasitoid larvae. Cocoons of the parasitoid were also checked daily and the time of emergence of wasps was recorded. On emergence, the number and sex ratio of the progeny were noted. The experiment was replicated six times with two females per replicate and a total of 60 larvae were exposed to parasitoid wasps for each treatment and control.

Cellular immune response of $S$. litura. To evaluate the effect of gallic acid on immune response of $S$. litura, 3rd instar larvae (12 days old) were fed on artificial diet supplemented with $\mathrm{LC}_{30}$ and $\mathrm{LC}_{50}$ concentrations for different time intervals i.e. 24, 48, 72, 96 and $120 \mathrm{~h}$. The treated larvae along with the larvae fed on control diet were kept at standard conditions of temperature and humidity i.e. $25 \pm 2{ }^{\circ} \mathrm{C}$ and $65 \pm 5 \%$, respectively. The hemolymph was collected by piercing the prothoracic legs with a sterile needle. For each time interval, ten larvae were randomly selected from each treatment group and the hemolymph was collected. The pooled hemolymph was used to study the total haemocyte count (THC) and deformities in haemocytes according to the protocol of Tauber and Yeager ${ }^{58}$ and Arnold and Hinks ${ }^{59}$, respectively. All experiments were replicated twice.

Gene expression of antioxidant enzymes. The relative expression of genes related with different antioxidant and detoxifying enzymes was measured using quantitative RT-PCR in the larvae of $S$. litura treated with the $\mathrm{LC}_{50}$ concentration of gallic acid at different intervals (48 and 72hours). The total RNA was extracted using Trizol method (Invitrogen). The quality and concentration of total RNA was checked using agarose gel electrophoresis (1\%) and nanodrop spectrophotometer. The iScript cDNA synthesis kit of Biorad was used to synthesize cDNA from $1.0 \mu \mathrm{g}$ of total RNA. The cDNA obtained was stored at $-20^{\circ} \mathrm{C}$ for further use after a dilution of tenfold. The mRNA sequences of various genes used to design primers of genes of interest were obtained from NCBI and actin was used as an internal reference gene (Table 9). Power SYBR Green PCR Master Mix (Applied Biosystems) with Step One Real Time PCR System (Applied Biosystems) was used to perform the qRT-PCR for different genes. The relative gene expression was determined by using the $2^{-\triangle \Delta C T}$ method to calculate the threshold values $(\mathrm{Ct})^{60}$.

Statistical analysis. The data were represented as their means \pm SE. The one-way analysis of variance (ANOVA) along with Tukey's test at $p \leq 0.05$ was done to check the differences in means. SPSS software for windows version 16.0 (SPSS Inc, Chicago), Microsoft office Excel 2007 (Microsoft Corp., USA) and ASSISTAT software were used to perform the statistical analysis. The $\mathrm{LC}_{30}$ and $\mathrm{LC}_{50}$ values were calculated by applying Probit analysis using SPSS software version 16.0 for windows.

Ethical approval. This article does not contain any studies with human participants or animals performed by any of the authors. 
Received: 1 June 2020; Accepted: 23 November 2020

Published online: 12 January 2021

\section{References}

1. Adeyemi, M. M. H. The potential of secondary metabolites in plant material as deterents against insect pests: a review. Afr. J. Pure Appl. Chem. 4, 243-246 (2010).

2. Walling, L. L. The myriad plant response to herbivores. J. Plant Growth Regul. 19, 195-216 (2000).

3. Croteau, R., Kutchan, T. M. \& Lewis, N. G. Natural products (Secondary metabolites). In Biochemistry \& Molecular Biology of Plants (eds Buchanan, B. B. et al.) 1250-1318 (American Society of Plants Biologists, Rockville, 2000).

4. Dewick, P. M. Medicinal Natural Products: A Biosynthetic Approach 2nd edn. (Wiley, Chichester, England, 2002).

5. Pham, A. \& Hwang, S. Chemical-based resistance of Brassica oleracea and Rorippa dubia in response to Spodoptera litura attack. J. Appl. Entomol. 144, 201-2011 (2019).

6. Niemetz, R. \& Gross, G. G. Enzymology of gallotannin and ellagitannin biosynthesis. Phytochemistry 66, 2001-2011 (2005).

7. Barbosa, P. et al. Plant allelochemicals and insect parasitoids effects of nicotine on Cotesia congregata (Say) (Hymenoptera:Braconidae) and Hyposoter annulipes (Cresson) (Hymenoptera: Ichneumonidae). J. Chem. Ecol. 12, 1319-1328 (1986).

8. Reitz, S. R. \& Trumble, J. T. Effects of linear furanocoumarins on the herbivore Spodoptera exigua and the parasitoid Archytas marmoratus: host quality and parasitoid success. Entomol. Exp. Appl. 84, 9-16 (1997).

9. Vinson, S. B. \& Barbosa, P. Interrelationships of nutritional ecology of parasitoids. In Nutritional Ecology of Insects, Mites, Spiders, and Related Invertebrates (eds Slansky, F., Jr. \& Rodriguez, J. G.) 673-695 (Wiley, New York, 1987)

10. Vinson, S. B. \& Iwantsch, G. F. Host Suitability for Insect Parasitoids. Annu. Rev. Entomol. 25, 397-419 (1980).

11. Duffey, S. S., Bloem, K. A. \& Campbell, B. C. Consequences of sequestration of plant natural products in plant insect-parasitoid interactions. In Interactions of Plant Resistance and Parasitoids and Predators of Insects (eds Boethel, D. J. \& Eikenbary, R. D.) 31-60 (Wiley, New York, 1986).

12. Rowell-Rahier, M., Pasteels, J. M. Phenolglucosides and interactions at three trophic levels: Salicaceae herbivores-predators. In Insect Plant Interactions Volume 2. pp. 75-94. Boca Raton, Florida: CRC. (1990).

13. Kester, K. M. \& Barbosa, P. Behavioral and ecological constraints imposed by plants on insect parasitoids: implications for biological control. Biol. Control 1, 94-106 (1991).

14. Dhir, B. C., Mohapatra, H. K. \& Senapati, B. Assessment of crop loss in groundnut due to tobacco caterpillar, Spodoptera litura (F.). Indian J. Plant Prot. 20, 215-217 (1992).

15. Armes, N. J., Wightman, J. A., Jadhav, D. R. \& Ranga-Rao, G. V. Status of insecticide resistance in Spodoptera litura in Andhra Pradesh, India. Pesticide Sci. 50, 240-248 (1997).

16. Kranthi, K. R., Jadhav, D. R., Wanjari, R. R., Ali, S. S. \& Russell, D. Carbamate and organophosphate resistance in cotton pests in India, 1995 to 1999. Bull. Entomol. Res. 91, 37-46 (2001).

17. Brower, J. H., Smith, L., Vail, P. V. \& Flinn, P. W. Biological control. In Integrated Management of Insects in Stored Products (eds Subramanyam, B. \& Hagstrum, D. W.) 223-286 (Marcel Dekker Inc, New York, 1996).

18. Reinert, J. A. \& King, E. W. Action of Bracon hehetor Say as a parasite of Plodia interpunctella at controlled densities. Ann. Entomol. Soc. Am. 64, 1335-1340 (1971).

19. Press, J. W., Flaherty, B. R. \& McDonald, I. C. Survival and reproduction of Bracon hebetor on insecticide-treated Ephestia cautella larvae. J. Georgia Entomol. Soc. 16, 231-234 (1981).

20. Gerling, D. \& Rotary, N. Hypersensitivity, resulting from host-unsuitability, as exemplified by two parasite species attacking Spodoptera littoralis (Lepidoptera: Noctuidae). Entomophaga 18, 391-396 (1973).

21. Selin-Rani, S. et al. Toxicity and physiological effect of quercetin on generalist herbivore, Spodoptera litura Fab. and a non-target earthworm Eisenia fetida Savigny. Chemosphere 165, 257-267 (2016).

22. Ghumare, S. S. \& Mukherjee, S. N. Performance of Spodoptera litura (Fabricius) on different host plants: influence of nitrogen and total phenolics of plants and mid-gut esterase activity of the insect. Indian J. Exp. Biol. 41, 895-899 (2003).

23 Ananthakrishnan, T. N., Gurusubramanian, G. \& Gopichandran, R. Influence of chemical profiles of host plant on the infestation diversity of Retithrips syriacus (Mayet). J. Biosci. 7, 483-489 (1991).

24. Bhattacharya, A. K. \& Chenchaiah, K. C. Seed coat phenolic compounds of Cajanus cajan as chemical barrier in formulation of artificial diet of Spodoptera litura (F.). Ann. Plant Prot. Sci. 15, 92-96 (2007).

25. Gautam, S., Samiksha, R., Arora, S. \& Sohal, S. K. Chemical profiling of polyphenols in extracts from bark of Acacia nilotica (Linn.) and their efficacy against Spodoptera litura (Fab.). Arch. Phytopathol. Plant Prot. 51, 41-53 (2018).

26. Bernays, E. A., Driver, G. C. \& Bilgener, M. Herbivores and plant tannins. Adv. Ecol. Res. 19, 263-302 (1989).

27. Sharma, R. \& Sohal, S. K. Oviposition response of melon fruit fly, Bactrocera cucurbitae (Coquillett) to different phenolic compounds. J. Biopest. 9, 46-51 (2016).

28. Nathan, S. S. \& Kalaivani, K. Combined effects of azadirachtin and nucleopolyhedrovirus (SpltNPV) on Spodoptera litura Fabricius (Lepidoptera: Noctuidae) larvae. Biol. Control 39, 96-104 (2006).

29. Deota, P. T. \& Upadhyay, P. R. Biological studies of azadirachtin and its derivatives against polyphagous pest, Spodoptera litura. Nat. Prod. Res. 19, 529-539 (2005).

30. Shu, B. et al. Azadirachtin affects the growth of Spodoptera litura Fabricius by inducing apoptosis in larval midgut. Frontiers Physiol. 9, 137 (2018).

31. De Moraes, C. M., Lewis, W. J., Pare, P. W., Alborn, H. T. \& Tumlinson, J. H. Herbivore-infested plants selectively attract parasitoids. Nature 393, 570-573 (1998).

32. Camphell, B. C. \& Duffey, S. S. Tomatine and parasitic wasps: potential incompatibility of plant antibiosis with biological control. Science 205, 700-702 (1979).

33. Campbell, B. C. \& Duffey, S. S. Alleviation of a-tomatine-induced toxicity to the parasitoid, Hyposoter exiguae, by phytosterols in the diet of the host, Heliothis zea. J. Chem. Ecol. 7, 927-946 (1981).

34. Bloem, K. A. \& Duffey, S. S. Interactive effect of protein and rutin on larval Heliothis zea and the endoparasitoid Hyposoter exiguae. Entomol. Exp. Appl. 54, 149-161 (1990).

35. El-Heneidy, A. H., Barbosa, P. \& Gross, P. Influence of dietary nicotine on fall armyworm, Spodoptera frugiperda and its parasitoid, the ichneumonid wasp Hyposoter annulipes. Entomol. Exp. Appl. 46, 227-232 (1988)

36. Reitz, S. R. \& Trumble, J. T. Tritrophic interactions among linear furanocoumarins, the Herbivore Trichoplusia ni (Lepidoptera: Noctuidae), and the polyembryonic parasitoid Copidosoma floridanum (Hymenoptera: Encyrtidae). Environ. Entomol. 25, 1391-1397 (1996).

37. Mondy, N. et al. Importance of sterols acquired through host feeding in synovigenic parasitoid oogenesis. J. Insect Physiol. 52, 897-904 (2006).

38. Punia, A., Chauhan, N. S., Kaur, S. \& Sohal, S. K. Effect of Ellagic acid on the larvae of Spodoptera litura (Lepidoptera: Noctuidae) and its parasitoid Bracon hebetor (Hymenoptera: Braconidae). J. Asia-Pac. Entomol. 23, 660-665 (2020).

39. Barbosa, P. \& Saunders, J. A. Plant allelochemicals: Linkages between herbivores and their natural enemies. Rec. Adv. Phytochem. 19, 107-137 (1985). 
40. Ode, P., Berenbaum, J. R., Zangerl, M. R. \& Hardy, I. C. W. Host plant, host plant chemistry and the polyembryonic parasitoid Copidosoma sosares: indirect effects in a tritrophic interaction. Oikos 104, 388-400 (2004).

41. Narendra, G., Khokhar, S. \& Ram, P. Effect of insecticides on some biological parameters of Trichogramma chilonis Ishii (Hymenoptera: Trichogrammtidae). J. Biol. Control 21, 130-134 (2013).

42. Abedi, Z., Saber, M., Gharekhani, G., Mehrvar, A. \& Kamita, S. G. Lethal and sublethal effects of azadirachtin and cypermethrin on Habrobracon hebetor (Hymenoptera: Braconidae). J. Econ. Entomol. 107, 638-645 (2014).

43. Radcliffe, E. B. Population responses of green peach aphid in Minnesota on potatoes treated with various insecticides. Proc. $N$ Cent. Branch Entomol. Soc. Am. 27, 103-105 (1972).

44. Flanders, S. E. Environmental resistance to the establishment of parasitic hymenoptera. Ann. Entomol. Soc. Am. 33, 245-253 (1940).

45. Kaplan, I., Carrillo, J., Garvey, M. \& Ode, P. J. Indirect plant-parasitoid interactions mediated by changes in herbivore physiology. Curr. Opin. Insect Sci. 14, 112-119 (2016).

46. Ayyangar, G. S. G. \& Rao, P. J. Changes in haemolymph constituents of Spodoptera litura (Fabr.) under the influence of azadirachtin. Indian J. Entomol. 52, 69-83 (1990).

47. Zibaee, A. \& Bandani, A. R. Effects of Artemisia annua L. (Asteracea) on the digestive enzymatic profiles and the cellular immune reactions of the Sunn pest, Eurygaster integriceps (Heteroptera: Scutellaridae), against Beauveria bassiana. Bull. Entomol. Res. 100, 185-196 (2009).

48. Kalyani, S. S. \& Holihosur, R. S. N. Toxic effect of crude aqueous leaf extracts of Clerodendron inerme, on the total haemocyte count of sixth instar larva of Helicoverpa armigera (H). Int. J. Innov. Res. Sci. Technol. 1, 221-224 (2015).

49. Saxena, B. P. \& Tikku, K. Effect of plumbagin on haemocytes of Dysdercus koenigii F. Proc. Anim. Sci. 99, 119-124 (1990).

50. Sakihama, Y. Plant phenolic antioxidant and prooxidant activities: phenolics-induced oxidative damage mediated by metals in plants. Toxicology 177, 67-80 (2002).

51. Krishnan, N. \& Sehnal, F. Compartmentalization of oxidative stress and antioxidant defense in the larval gut of Spodoptera littoralis. Arch. Insect Biochem. Physiol. 63, 1-10 (2006).

52. Lindroth, R. L. Biochemical detoxication: mechanism of differential tiger swallowtail tolerance to phenolic glycosides. Oecologia 81, 219-224 (1989).

53. Despres, L., David, J. P. \& Gallet, C. The evolutionary ecology of insect resistance to plant chemicals. Trends Ecol. Evol. 22, 298-307 (2007).

54. Terriere, L. C. Induction of detoxication enzymes in insects. Annu. Rev. Entomol. 29, 71-88 (1984).

55. Li, X. C., Schuler, M. A. \& Berenbaum, M. R. Molecular mechanisms of metabolic resistance to synthetic and natural xenobiotics. Annu. Rev. Entomol. 52, 231-253 (2007).

56. Koul, O. G., Singh, R. \& Singh, J. Bioefficacy and mode-of-action of Aglaroxin B and Aglaroxin C from Aglaia elaeagmoidea (syn. A. Irox burghiana) against Helicoverpa armigera and Spodoptera litura. Biopesticides Int. 1, 54-64 (2005).

57. Waldbauer, G. P. The Consumption and Utilization of Food by Insects. Adv. Insect Physiol. 5, 229-288 (1968).

58. Tauber, O. E. \& Yeager, J. F. On total hemolymph (blood) cell counts of insects I. Orthoptera, odonata, hemiptera, and homoptera. Ann. Entomol. Soc. Am. 28, 229-240 (1935).

59. Arnold, J. W. \& Hinks, C. F. Insect haemocytes under light microscopy: techniques. In Insect Haemocyte Development, Forms, Functions and Techniques (ed. Gupta, A. P.) 531-538 (Cambridge University Press, Cambridge, 1979).

60. Livak, K. J. \& Schmittgen, T. D. Analysis of relative gene expression data using real-time quantitative PCR and the 2(-Delta Delta C(T)) Method. Methods 25, 402-408 (2001).

\section{Acknowledgements}

The grant received from Department of Science and Technology/INSPIRE fellowship New Delhi (India) for carrying out the research work is gratefully acknowledged.

\section{Author contributions}

A.P., S.K.S. and S.K. conceived and designed the experiments, A.P. and N.S.C. performed the experiments. The data obtained was analyzed by A.P., N.S.C., A.K.K. and D.S. A.P. wrote the manuscript. All authors read and approved the final manuscript.

\section{Competing interests}

The authors declare no competing interests.

\section{Additional information}

Correspondence and requests for materials should be addressed to S.K.S.

Reprints and permissions information is available at www.nature.com/reprints.

Publisher's note Springer Nature remains neutral with regard to jurisdictional claims in published maps and institutional affiliations.

Open Access This article is licensed under a Creative Commons Attribution 4.0 International License, which permits use, sharing, adaptation, distribution and reproduction in any medium or format, as long as you give appropriate credit to the original author(s) and the source, provide a link to the Creative Commons licence, and indicate if changes were made. The images or other third party material in this article are included in the article's Creative Commons licence, unless indicated otherwise in a credit line to the material. If material is not included in the article's Creative Commons licence and your intended use is not permitted by statutory regulation or exceeds the permitted use, you will need to obtain permission directly from the copyright holder. To view a copy of this licence, visit http://creativecommons.org/licenses/by/4.0/.

(C) The Author(s) 2021 